\title{
CORRESPONDENCE
}

\section{Invest in a DNA bank for all species}

To complement its efforts to conserve nature in the wild, the Convention on Biological Diversity should develop a comprehensive and adequately funded global effort to preserve intact genomes and viable cells for every known species and for new species as they are discovered. Super-cold freezing is the current method of choice, from a whole rhino skin to a bacterium.

Freezing tissue costs US\$200-300 per species, with negligible maintenance costs. Preserving material from all the roughly 1.8 million known species would cost about $\$ 540$ million. The United States spends more than $\$ 1$ billion every four days on the war in Afghanistan. So less than $\$ 1$ billion to preserve the DNA of all known species on Earth, with whom we share billions of years of evolutionary history, seems like good value.

Keeping DNA intact for future research has the potential for cloning and for the resurrection of extinct species. Some worry that we might then do less to save life in the wild. But it does not make sense to lose genomes forever just because we lack the motivation to pursue conservation at the same time.

Plants are currently better represented in frozen collections than animals, with the best coverage for agricultural species. But seed banks collectively hold viable tissue of just a fraction of all known species. There is no shared plan or funding for an entire encyclopedia of life.

We need an inventory of what is already preserved and a plan for preserving what is not. We need shared protocols for collection and storage, and ways to ensure that countries can participate without fear of losing out on revenue from future commercial uses.

Flexible guidance on priorities would be helpful, for example to preserve the most genetically divergent species, to address threatened species in good time, and to engage the international community in collecting and storing tissue.

William Y. Brown Brookings Institution, Washington DC, USA.wbrown@brookings.edu

\section{Learn from Ireland's knowledge economy}

You highlight China's scientific investment drive (Nature 476, $5 ; 2011)$. This is a reminder that nations with little experience of modern large-scale investment in science may be jumping into ill-planned knowledge-economy ventures that could have serious long-term consequences.

Take Ireland, for example. An explosion in scientific investment quickly attracted many scientists to the country and saw it climb up the international scientific rankings. Now fundamental flaws in the Irish system are showing up as the funding fades.

Having been recruited from the United States by Science Foundation Ireland (SFI), we were shocked to discover how poorly planned and disjointed the research system seems to be in Ireland. The SFI does not make clear to either the host institution or the recruited scientist that their investment in the recruit is short-term. One learns after recruitment that universities often do not want to employ researchers for longer than 4 years, to avoid commitments under the European Union's fixed-term workers' contract.

Continuous changes by the SFI to core funding programmes, combined with cronyism in the Irish university system, mean that the career structures and support needed to build a stable research environment are missing.

Many Irish researchers are discontented; some have left or are leaving the country (D. Ahlstrom The Irish Times 17 December 2010). Ireland seems not to realize that it is scientists who drive research, focusing instead on large capital investments in impressive research buildings that bolster the image of an economic strategy.

Many countries try to emulate the US academic system. This is based on money, yes, but also on supporting talent through the tenure track. Ignore this and valuable government finances will be wasted and the careers of young scientists will hit a dead end. Developing a knowledge economy requires some knowledge of how to do it properly.

Mojgan Naghavi Columbia University, New York, USA. mn2034@columbia.edu

Derek Walsh New York

University, New York, USA.

\section{Nanomaterials should be defined}

Andrew Maynard argues against defining engineered nanomaterials for regulatory purposes (Nature 475, 31; 2011). But such a definition is urgently needed, especially for particulate nanomaterials. The aim should be to identify a general class of materials for attention - whether they are benign or hazardous.

Nanomaterials have many properties not shared by their larger-scale counterparts, some of which have safety implications. More and more products containing novel nanomaterials are reaching the market.

In light of legitimate public concerns and the resultant political responses, a revision and adaptation of legislation is considered necessary. The European Cosmetic Products Regulation of 2009 and a European Parliament legislative resolution on food information adopted in July 2011 both stipulate that nanomaterial ingredients should be strictly labelled. The European Parliament has called for the adoption of a "comprehensive science-based" definition of 'nanomaterial'.

Maynard's point that such materials are heterogeneous is justified. However, they all have structures on the nanoscale, which modify their other properties. Size is therefore the most appropriate parameter on which to base a broad definition (see also G. Lövestam et al. EUR 24403 EN, European Commission Joint Research Centre; 2010). A definition is required for labelling purposes, and would assist industry and regulators in identifying where specific safety assessments might be necessary. We acknowledge that it would need revision in line with fresh scientific evidence. Hermann Stamm European Commission Joint Research Centre, Institute for Health and Consumer Protection, Ispra, Italy. hermann.stamm@ec.europa.eu

\section{Stats for papers let authors track impact}

Your website now enables authors to access download statistics for their publications in journals of the Nature Publishing Group (see go.nature.com/9wmgcu), a feature I have found useful. What's more, information on median downloads for all articles in a specific journal enables me to evaluate that journal's impact in the wider scientific community. Si Ming Man University of Cambridge, Cambridge, UK. smm77@cam.ac.uk

\section{CONTRIBUTIONS}

Correspondence may be sent to correspondence@ nature.com after consulting the author guidelines at go.nature.com/cmchno 